\title{
Morphometric studies in rectal biopsy specimens from patients with ulcerative colitis: effect of oral 5 amino salicylic acid and rectal prednisolone treatment
}

\author{
A M Zaitoun, I Cobden, H Al Mardini, C O Record
}

\begin{abstract}
Morphometric measurements were performed on rectal biopsy specimens from 10 normal control subjects and 33 patients with a relapse of distal ulcerative colitis before and after treatment for four weeks in a double blind controlled trial with oral eudragit $S$ coated 5 amino salicylic acid $(n=12)$ or rectal prednisolone enemas $(n=15)$. Measurements were assessed using a computer aided measuring system and a counting technique. When untreated patients were compared with the control group there were significant decreases in the area and height of the surface epithelium, in the area of crypt epithelium, and in the ratios of goblet cells to epithelial cells and of surface epithelium to lamina propria. The vascular and lamina propria areas and the number of intraepithelial polymorphs were increased. Treatment with 5 amino salicylic acid and corticosteroids resulted in similar morphological improvements: there was an increase in the area and height of the surface epithelium and the ratios of surface epithelium to lamina propria and of surface to crypt cell height. The ratio of goblet cells to epithelial cells also increased after treatment, while the numbers of polymorphs in the surface and crypt epithelium and lumen decreased. In conclusion, computerised morphometry is valuable for the assessment of the treatment of patients with ulcerative colitis and that in the doses used both treatments were of similar efficacy.
\end{abstract}

The histological diagnosis of ulcerative colitis is based upon the subjective assessment of some reliable criteria such as mucosal ulceration, mucus depletion, crypt abscesses, and absence of epithelioid granulomata. Differentiation of ulcerative colitis from Crohn's colitis and infective colitis can sometimes be difficult while responses to treatment are subjective and can be misinterpreted. Morphometric analysis, however, being a quantitative assessment may be more reliable and reproducible than subjective assessment. Simple quantitative methods are based on the use of linear measurements using an eye piece graticule. ${ }^{1-4}$ More sophisticated computerised image analysis systems have also been used for the assessment of rectal biopsy specimens $^{5-10}$ and to discriminate between various types of inflammatory bowel disease. ${ }^{5}$

Anti-inflammatory drugs such as 5 amino salicylic acid (5ASA) $)^{11}$ and corticosteroids ${ }^{13}$ are frequently used to treat patients with ulcerative colitis and a comparison between 5ASA and prednisolone enemas for the treatment of patients with active ulcerative colitis has recently been reported. ${ }^{14}$

This study aimed to assess the morphological changes in mucosal biopsy specimens from patients with ulcerative colitis in comparison with a normal control group using morphometric and counting techniques. We have also examined morphometric parameters in patients before and after treatment with oral 5ASA and rectally administered corticosteroids.

\section{Methods}

Thirty three patients with active distal ulcerative colitis were included in this study. The diagnosis of ulcerative colitis was made on the basis of sigmoidoscopy, clinical, radiological, and histological findings. Twelve patients were randomly allocated to treatment with oral eudragit $S$ coated 5ASA (3.2 g/day; Asacol; Smith, Kline and French) while a further 15 patients were allocated to treatment with prednisolone enemas (20 mg/day; Predsol; Glaxo). Biopsy specimens were taken before and four weeks after treatment. Six additional patients were assessed only before treatment while 10 rectal biopsy specimens that proved to be histologically normal were used as a control group. Specimens were processed routinely, cut into $4 \mu \mathrm{m}$ thick sections, and stained with haematoxylin and eosin.

\section{COMPUTERISED MORPHOMETRY}

Measurements were made with no prior knowledge of the biopsy sequence or the treatment taken by the patients. Specimens were examined using the MOP-Videoplan semiautomated image analysis system (CARL-ZEISS Ltd). A self illuminated cursor was superimposed on the microscope field by viewing it through a drawing tube attached to a conventional Olympus microscope. The relevant structures were delineated by moving a cursor over the surface of a digitising tablet. The traced coordinates were recorded by computer and converted by the measuring software into a set of values for the preselected parameters. Figure 1 shows some of the variables measured and Table I lists these parameters with the derived variables. Parameters $2,5,9,10,11$, 12 , and 13 (Table I) were measured using a magnification of $\times 500$. The remaining variables were obtained at a magnification of $\times 250$. 
Figure 1: Some of the variables measured in each section. $H=$ mucosal height; $D=$ depth of the crypt; $W=$ width of the crypt; $L=$ length of muscularis mucosa (MM). $E=$ surface epithelial cell height; $F=$ crypt epithelial cell height; and shaded area $=$ area of surface epithelium (A.Ep).

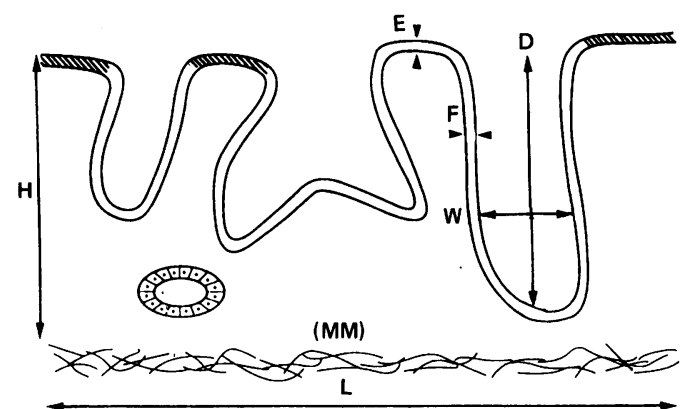

Measurements were aided by an eye piece graticule (index squared grid). Some of the measurements (1-3, 5, 11-13, and lamina propria; Table I) were related to a standard length of the muscularis mucosae.

\section{COUNTING TECHNIQUE}

The number of nuclei per gland was obtained by counting the nuclei of epithelial cells within at least nine glands cut transversely. The mitotic index of the crypt (MI) was obtained by counting over 200 nuclei and calculated by the following equation:

$$
M I=\frac{\text { Number of mitosis } \times 100}{\text { Total number of cells }}
$$

Goblet cell ratios within the surface and crypt epithelium were calculated in similar ways by counting goblet cells in relation to over 200 nuclei of epithelial cells in each compartment.

\section{STATISTICAL ANALYSIS}

Results are expressed as mean (SE). The significance of the differences between the means for each parameter before and after treatment was determined using the two tailed paired Student's $t$ test. The differences between control subjects and untreated patients, between 5ASA and corticosteroid treated patients, and between control

TABLE I Measured values obtained by morphometric analysis and derived values in rectal biopsy specimens

Measured values obtained by morphometric analysis

(1) Mucosal area: total area of mucosa between luminal surface and muscularis mucosa $/ 100 \mu \mathrm{m}$ muscularis mucosa.

(2) Area of the surface epithelium/100 $\mu$ m muscularis mucosa (A.Ep/100 $\mu \mathrm{mMM}$; shown hatched in Fig 1).

(3) Area of crypts (epithelium +lumen)/100 $\mu \mathrm{m}$ of muscularis mucosa.

4) Length of the muscularis mucosa $(\mu \mathrm{m})$. ((L) in Fig 1.$)$

(5) Areas of blood vessels in relation to $10^{4}, \mu \mathrm{m}^{2}$ of the lamina propria/100 $\mu \mathrm{m}$ muscularis mucosa (Ves/LP)

(6) Mucosal height: $(\mu \mathrm{m})$. ((H) in Fig 1.)

(7) Depth of the crypt: Linear distance between the mouth and the base of the crypt in $\mu \mathrm{m}$. ((D) in Figure 1 .)

(8) Maximum width of the crypt in $\mu \mathrm{m}$. ((W) in Fig 1 .)

(9) Cell height of the surface epithelium $(\mu \mathrm{m})$. ((E) in Fig 1 .

(10) Cell height of the crypt epithelium $(\mu \mathrm{m})$. ((F) in Fig 1.)

(11) No of nuclei per crypt

(12) Goblet cell ratio: ratio of goblet to epithelial cells.

(12) Goblet cell ratio: ratio of goblet to epithelial cells

(13) Mitotic index: no of mitosis/100 epithelial cells.
(14) Intraepithelial polymorphs within the surface epithelium/ Intraepithelial polymorphs within the surface
$10^{3} \mu \mathrm{m}$ of muscularis mucosal length (IEP/S)

(15) Intraepithelial polymorphs within the crypt epithelium $/ 10^{3}$ $\mu \mathrm{m}$ of muscularis mucosal length (IEP/C)

(16) Luminal polymorphs of the crypt $/ 10^{3} \mu \mathrm{m}$ of muscularis mucosal length (ILP)

Derived values

(1) The ratio of crypt depth/mucosal height $(\mathrm{D} / \mathrm{H})$.

(1) The ratio of crypt depth/mucosal height $(\mathrm{D} / \mathrm{H})$.
(2) Lamina propria (LP): Total area of mucosa - area of surface Lamina propria (LP):
epithelium and crypts.

(3) The ratio of surface epithelium/lamina propria (A.Ep/LP) $(\%) / 100 \mu \mathrm{m}$ muscularis mucosa.

(4) The cell height ratio: surface (S)/crypt (C). subjects and patients after treatment by each drug were determined using the non-paired Student's $t$ test. The study was approved by the Ethical Committee of Newcastle Health Authority.

\section{Results}

UNTREATED PATIENTS AND CONTROLS

Table II shows the results obtained by morphometric analysis and the counting technique for control subjects and untreated patients with ulcerative colitis. In untreated patients (Fig 2) there was a $50 \%$ reduction in the area of the superficial epithelium $(p<0.001)$ and the area of the crypts $(\mathrm{p}<0.001)$ with a $104 \%$ increase in the area of the lamina propria $(\mathrm{p}<0.001)$ compared with the control group. Thus the area of the surface epithelium compared with lamina propria (A.Ep/Lp) was decreased by $75 \%$ $(p<0.001)$. The mucosal height and crypt width were also increased in untreated patients $(p<0.001)$. There was a $56 \%$ decrease in the cell height of the superficial epithelium $(p<0.001)$ while in the crypt, epithelial cell height did not significantly change from the control value. There were also significant alterations in the crypt goblet cell to epithelial cell ratio (decreased) and mitotic index (increased). Vascularity within the lamina propria was increased by $151 \%(\mathrm{p}<0 \cdot 001)$. Polymorph infiltration (number of polymorphs) in the superficial epithelium, the crypt epithelial lining, and lumen was significantly $(\mathrm{p}<0.001)$ increased in each compartment in untreated patients compared with the control group (Fig 3).

\section{MORPHOLOGICAL CHANGES IN PATIENTS TREATED} BY 5ASA

The changes in mucosal biopsy specimens in patients before and after treatment with 5ASA are shown in Table III and Figures 2-6. After treatment there were increases in the area of the superficial (from 1664 to $3522 \mu \mathrm{m}^{2} ; \mathrm{p}<0.001$ ) and crypt epithelium $(p<0.01)$ while the area of the lamina propria decreased $(\mathrm{p}<0.05 ;$ Fig 2$)$. Thus for every patient treated with 5ASA there

TABLE II Results obtained by morphometric analysis and counting technique for 10 control subjects and 33 untreated patients with ulcerative colitis

\begin{tabular}{|c|c|c|}
\hline Measured or derived value & $\begin{array}{l}\text { Controls } \\
\text { Mean }(S E)\end{array}$ & $\begin{array}{l}\text { Untreated patients } \\
\text { Mean }(S E)\end{array}$ \\
\hline $\begin{array}{l}\text { A.Ep/100 } \mu \mathrm{mMM} \\
\text { Crypt area/100 } \mu \mathrm{mMM}\left(\times 10^{3}\right) \\
\text { LP area/100 } \mu \mathrm{mMM}\left(\times 10^{3}\right) \\
\text { Ves/LP }\left(10^{4} \mu \mathrm{m}^{2}\right) \\
\text { A.Ep/LP }(\%) / 100 \mu \mathrm{mMM} \\
\text { Depth crypt }(\mathrm{D}) \\
\text { Mucosa height }(\mathrm{H}) \\
\text { D/H ratio } \\
\text { Goblet cell ratio (surface) } \\
\text { Cell height (surface; S) } \\
\text { Cell height (crypt; C) } \\
\text { Cell height ratio (S/C) } \\
\text { Width crypt }(\mu \mathrm{m})(\mathrm{W}) \\
\text { No nuclei/crypt } \\
\text { Goblet cell ratio (crypt) } \\
\text { Mitotic index (crypt) } \\
\text { IEP/S } \\
\text { IEP/C } \\
\text { ILP }\end{array}$ & $\begin{array}{l}3912(338) \\
28(2) \\
25(1) \\
74(5) \\
15 \cdot 6(1 \cdot 1) \\
481(35) \\
528(38) \\
0 \cdot 9(0 \cdot 01) \\
8(1 \cdot 4) \\
43(1 \cdot 9) \\
29(1 \cdot 2) \\
1 \cdot 5(0 \cdot 1) \\
76(2) \\
35(1 \cdot 5) \\
38(1 \cdot 8) \\
1 \cdot 1(0 \cdot 4) \\
0 \cdot 6(0 \cdot 2) \\
1 \cdot 1(0 \cdot 4) \\
0(0)\end{array}$ & $\begin{array}{l}1819(150)^{\star \star} \\
15(1)^{\star \star} \\
51(3)^{\star \star} \\
186(16)^{\star \star} \\
3 \cdot 9(0 \cdot 4)^{\star \star} \\
526(27) \\
714(33)^{\star \star} \\
0 \cdot 7(0 \cdot 02)^{\star \star} \\
10(1 \cdot 1) \\
19(0 \cdot 9)^{\star \star} \\
30(1 \cdot 2) \\
0 \cdot 7(0 \cdot 03)^{\star \star} \\
103(5)^{\star \star} \\
38(1 \cdot 4) \\
22(2)^{\star \star} \\
3 \cdot 4(0 \cdot 3)^{\star \star} \\
12(1 \cdot 7)^{\star \star} \\
22(2 \cdot 2)^{\star \star} \\
17(4)^{\star \star}\end{array}$ \\
\hline
\end{tabular}

${ }^{\star \star} \mathrm{p}<0 \cdot 001$. For abbreviations see Table I. 


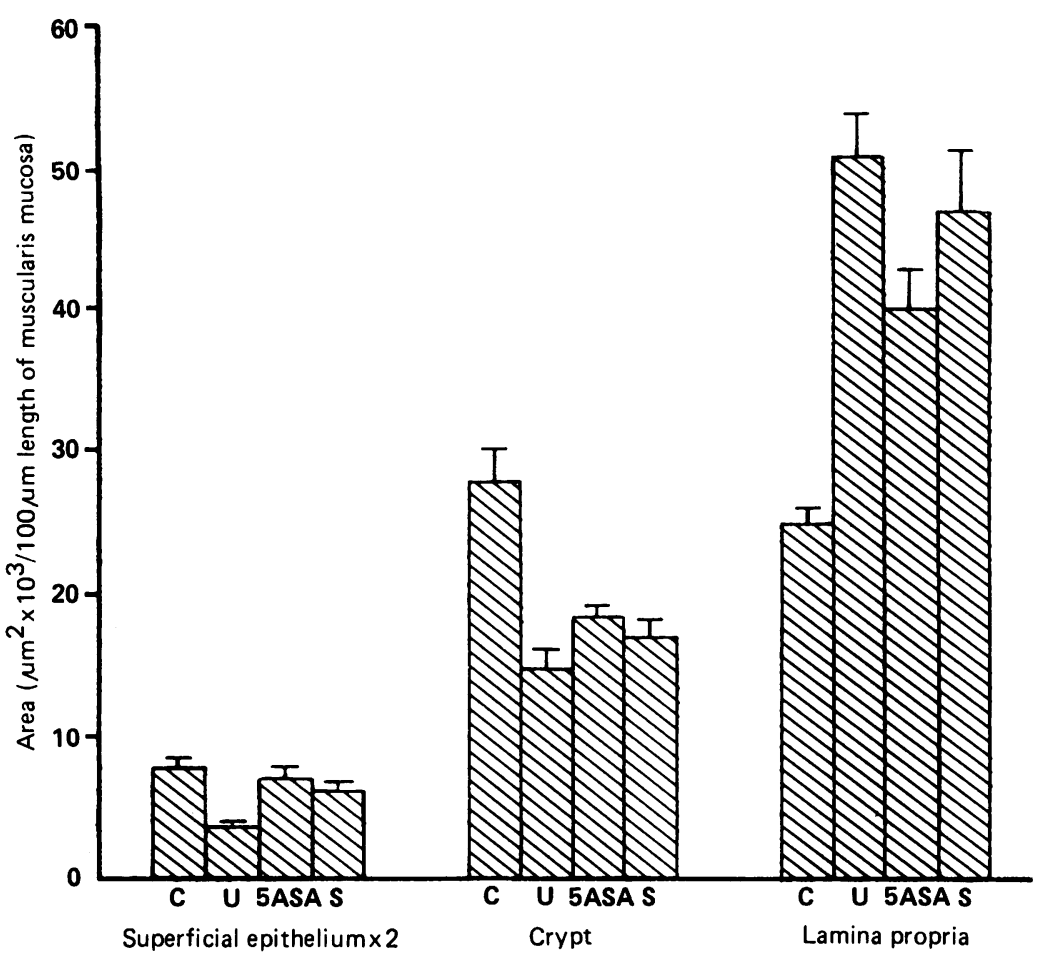

Figure 2: The areas of the surface epithelium (left), the crypt (middle), and the lamina propria (right) in 10 control subjects $(C), 33$ untreated patients with ulcerative colitis $(U), 12$ patients treated by 5 amino salicylic acid (SASA), and 15 patients treated with rectal steroids $(S)$. Values are expressed as $\mu m^{2} \times 10^{3} / 100 \mu m$ of muscularis mucosa (mean $(S E)$ ). All values were significantly different from controls.

was an increase in ratio of the areas of surface epithelium to lamina propria (Fig 4), the mean value being increased by $162 \%(p<0.01)$. There were no significant changes in mucosal height, crypt depth to mucosal height ratio, or in the width of the crypt. The cell height of the superficial epithelium was significantly increased by treatment $(\mathrm{p}<0.001)$ but was unchanged in the crypt. The surface to crypt (S/C) cell height ratios for each patient are shown in Figure 5.

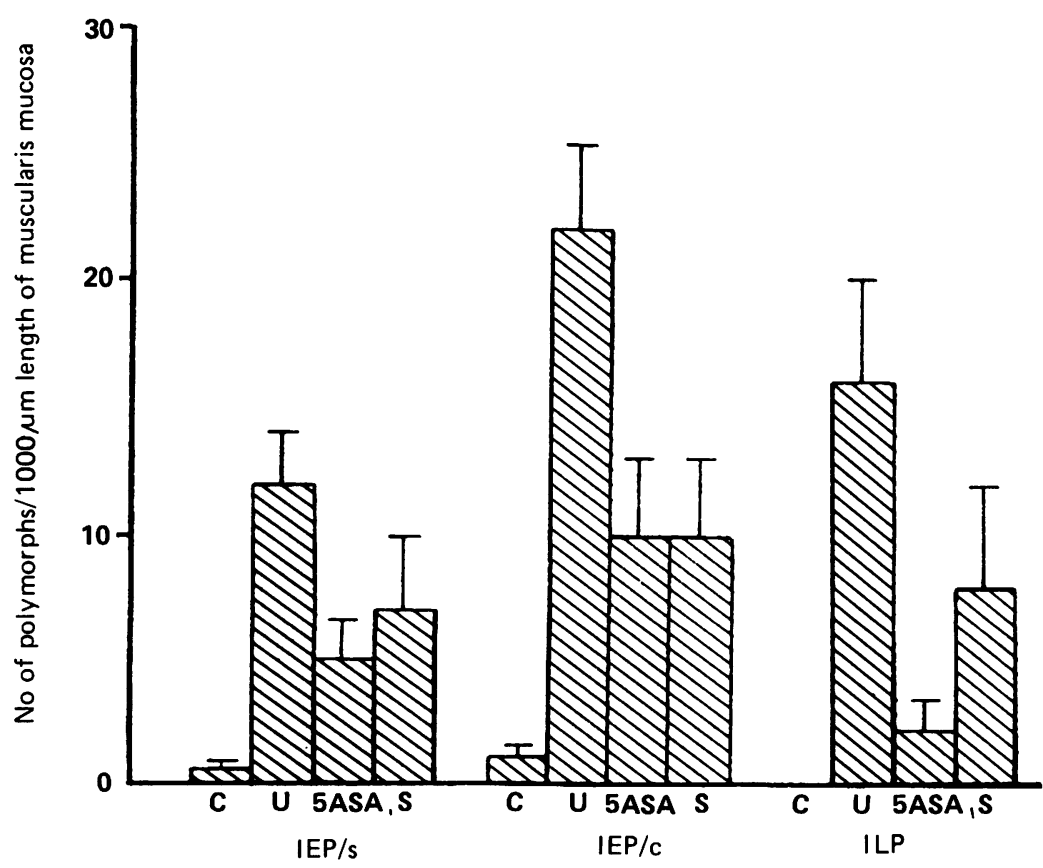

Figure 3: The numbers of surface intraepithelial polymorphs (IEP/s), crypt intraepithelial polymorphs $(I E P / c)$, and crypt lumen polymorphs $(I L P)$ per $1000 \mu m$ of muscularis mucosa in 10 control subjects $(C), 33$ untreated patients with ulcerative colitis $(U), 12$ patients after treatment with 5 amino salicylic acid (5ASA), and 15 patients treated with systemic corticosteroids $(S)$ (mean $(S E))$. All values were significantly different from controls.
There was an increase in 10 of the 12 patients treated by $5 A S A$, the mean value being significantly increased $(p<0 \cdot 001)$. Goblet cell to epithelial cell ratios (Fig 6) were increased in 10 of the 12 patients $(p<0 \cdot 05)$. Polymorph infiltration was decreased after treatment from 14 (3)5 (2) in the superficial epithelium $(\mathrm{p}<0.05)$, from 28 (4)-10 (3) in the crypt epithelium $(\mathrm{p}<0.01)$, and from 16 (4)-2 (1) polymorphs in the lumen of the crypt $(\mathrm{p}<0.001)$ after 5ASA treatment (Fig 3).

\section{MORPHOLOGICAL CHANGES IN PATIENTS TREATED} WITH CORTICOSTEROIDS

Table IV lists the morphological changes in 15 patients with ulcerative colitis treated with prednisolone enemas. There were significant increases in the areas of superficial $(p<0.02)$ and crypt $(\mathrm{p}<0.05)$ epithelium after treatment (Fig 2) while the surface epithelium to lamina propria ratio was also increased in 12 of the 15 patients. The mean value of the latter was increased by $76 \%(\mathrm{p}<0.05)$. The S/C cell height ratio was significantly increased $(p<0.001)$ after treatment, an improvement being seen in 14 of the 15 patients (Fig 5). The goblet cell ratio increased in 11 of 15 patients (Fig 6), the mean value being significantly increased from 21(3)-37(4) $(\mathrm{p}<0.01)$.

As in patients treated with 5ASA, vascularity, mucosal height, crypt depth to mucosal height ratio, width of the crypt, number of nuclei of the crypt, and mitotic index were not significantly altered by corticosteroid treatment. Polymorphs within the crypt epithelium were reduced from $22(3)-10(3)(\mathrm{p}<0 \cdot 02$; Fig 3$)$.

COMPARISON BETWEEN 5ASA, CORTICOSTEROIDS, AND CONTROLS

Results obtained after treatment with 5ASA (12 patients) compared with those obtained after treatment with steroids (15 patients) showed no significant difference in any of the parameters obtained by computer analysis and counting technique.

The results obtained after treatment with both

TABLE III Results obtained by morphometric analysis and counting technique in 12 patients treated with 5 amino salicylic acid

\begin{tabular}{|c|c|c|}
\hline & $\begin{array}{l}\text { Untreated } \\
\text { Mean }(S E)\end{array}$ & $\begin{array}{l}\text { Treated } \\
\text { Mean }(S E)\end{array}$ \\
\hline $\begin{array}{l}\text { A.Ep/100 } \mu \mathrm{mMM} \\
\text { Crypt area/100 } \mu \mathrm{mMM}\left(\times 10^{3}\right) \\
\text { LP area/100 } \mu \mathrm{mMM}\left(\times 10^{3}\right) \\
\text { Ves/LP }\left(10^{+} \mu \mathrm{m}^{2}\right) \\
\text { A.Ep/LP }(\%) / 100 \mu \mathrm{mMM} \\
\text { Depth crypt }(\mathrm{D}) \\
\text { Mucosa height }(\mathrm{H}) \\
\text { D/H ratio } \\
\text { Goblet cell ratio (surface) } \\
\text { Cell height (surface; S) } \\
\text { Cell height (crypt; C) } \\
\text { Cell height ratio (S/C) } \\
\text { Width crypt }(\mu \mathrm{m})(\mathrm{W}) \\
\text { No nuclei/crypt } \\
\text { Goblet cell ratio (crypt) } \\
\text { Mitotic index (crypt) } \\
\text { IEP/s } \\
\text { IEP/C } \\
\text { ILP }\end{array}$ & $\begin{array}{l}1664(178) \\
13(2) \\
51(5) \\
195(25) \\
3 \cdot 7(0 \cdot 5) \\
562(50) \\
711(64) \\
0 \cdot 8(0 \cdot 02) \\
8(2) \\
20(1 \cdot 5) \\
29(2) \\
0 \cdot 7(0 \cdot 1) \\
89(12) \\
37(1) \\
20(3) \\
3 \cdot 5(0 \cdot 6) \\
14(3) \\
28(4) \\
16(4)\end{array}$ & $\begin{array}{l}3522(378)^{\star \star} \\
19(1)^{\star} \\
39(3) \dagger \\
145(28) \\
9 \cdot 7(1 \cdot 4)^{\star} \\
477(30) \dagger \\
645(34) \\
0 \cdot 7(0 \cdot 02) \\
21(4)^{\star} \\
35(3 \cdot 4)^{\star \star} \\
31(1 \cdot 4) \\
1 \cdot 1(0 \cdot 1)^{\star \star} \\
97(9) \\
43(2) \ddagger \\
43(5) \dagger \\
3 \cdot 1(0 \cdot 4) \\
5(2) \dagger \\
10(3)^{\star} \\
2(1)^{\star \star}\end{array}$ \\
\hline
\end{tabular}

${ }^{\star} \mathrm{p}<0.01 ;{ }^{\star \star} \mathrm{p}<0.001 ;+\mathrm{p}<0.05 ; \neq \mathrm{p}<0.02$. For abbreviations see Table I. 

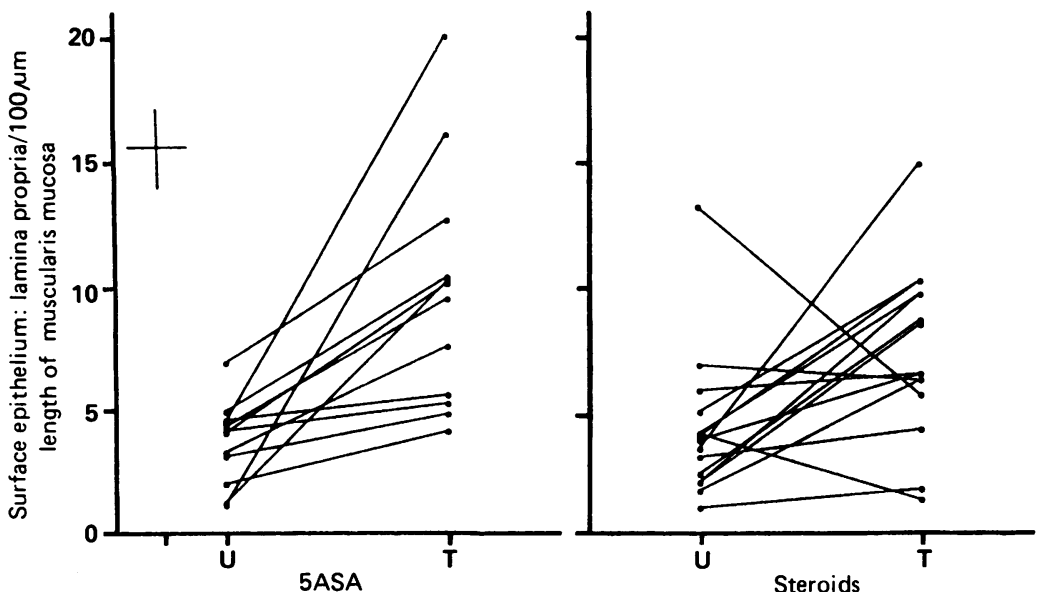

Figure 4: The ratio of the area of surface epithelium over the area of the lamina propria per unit length of the muscularis mucosa from patients with ulcerative colitis before $(U)$ and after $(T)$ treatment with 5 amino salicylic acid (5ASA) and corticosteroids. The mean value of the control group is also shown.
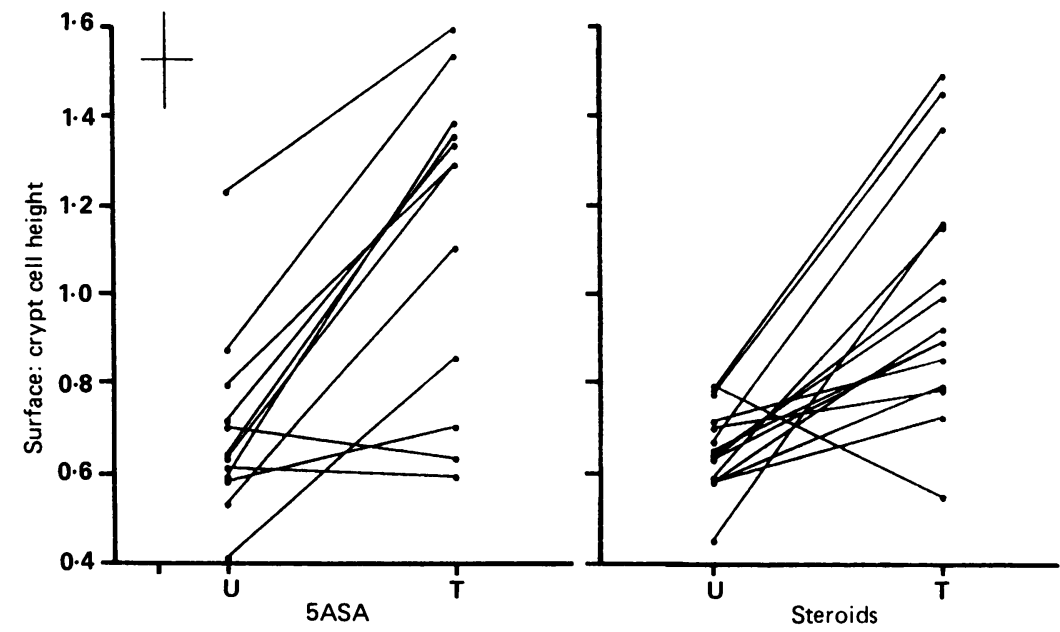

Figure 5: The ratio of surface epithelial cell height to crypt epithelial cell height in patients with ulcerative colitis before $(U)$ and after $(T)$ treatment by 5 amino salicylic acid $(5 A S A)$ and corticosteroids. The mean value of the control group is also shown.
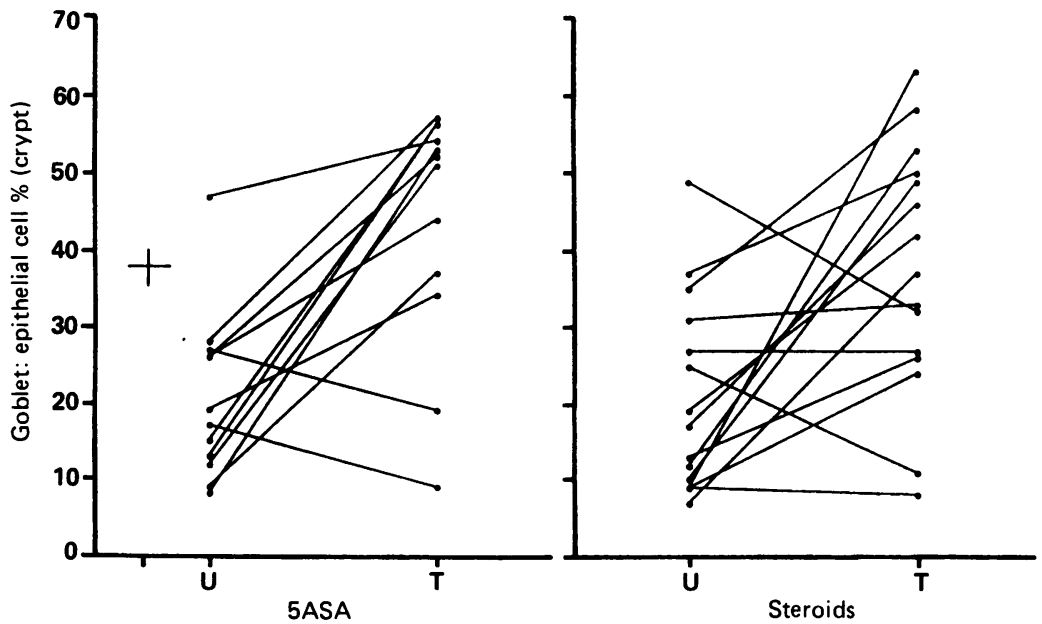

Figure 6: Goblet cell ratio (goblet cells/100 epithelial cells) of the crypt epithelium in patients with ulcerative colitis before $(U)$ and after $(T)$ treatment with 5 amino salicylic acid (5ASA) and corticosteroids. The mean value of the control group is also shown.

drugs were also compared with the control group. Figure 2 shows the mucosal changes in control, untreated, and treated patients. The areas of the surface epithelium and crypt increased to $90 \%$ and $78 \%(p=N S)$ and $68 \%$ and $61 \%$ of the control values $(\mathrm{p}<0.001)$ after 5ASA and corticosteroids respectively. The ratio of
TABLE IV Results obtained by morphometric analysis and counting technique in 15 patients treated by rectal prednisolone

\begin{tabular}{|c|c|c|}
\hline Measured and derived values & $\begin{array}{l}\text { Untreated } \\
\text { Mean }(S E)\end{array}$ & $\begin{array}{l}\text { Treated } \\
\text { Mean }(S E)\end{array}$ \\
\hline 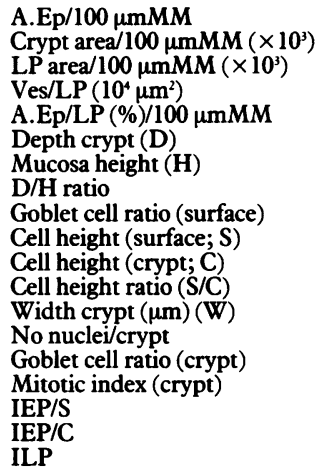 & $\begin{array}{l}1861(294) \\
13(2) \\
47(4) \\
190(26) \\
4 \cdot 2(0 \cdot 8) \\
459(26) \\
659(32) \\
0 \cdot 7(0 \cdot 03) \\
8(2) \\
19(0 \cdot 95) \\
29(1 \cdot 4) \\
0 \cdot 7(0 \cdot 02) \\
107(6 \cdot 9) \\
38(2 \cdot 6) \\
21(3) \\
3 \cdot 4(0 \cdot 04) \\
13(3) \\
22(3) \\
21(8)\end{array}$ & $\begin{array}{l}3044(293) \ddagger \\
17(1) \dagger \\
47(4) \\
194(27) \\
7 \cdot 4(0 \cdot 9) \dagger \\
475(29) \\
669(46) \\
0 \cdot 7(0 \cdot 03) \\
17(3) \dagger \\
33(2 \cdot 8)^{\star \star} \\
33(1 \cdot 4) \dagger \\
1 \cdot 0(0 \cdot 1)^{\star \star} \\
113(5 \cdot 1) \\
42(2 \cdot 4) \\
37(4)^{\star} \\
3 \cdot 2(0 \cdot 4) \\
7(3) \\
10(3) \ddagger \\
8(4)\end{array}$ \\
\hline
\end{tabular}

${ }^{\star} \mathrm{p}<0.01 ;{ }^{\star \star} \mathrm{p}<0.001 ; \mathrm{tp}<0.05 ; \neq \mathrm{p}<0.02$.

For abbreviations see Table I.

surface epithelium to lamina propria also increased to $62 \%$ and $47 \%$ of the control value after 5ASA $(\mathrm{p}<0.01)$ and steroids $(\mathrm{p}<0.001)$ while the crypt goblet to epithelial cell ratio increased after treatment by both drugs to a level similar to that of the control value $(p=N S)$. The mucosal polymorph infiltration of normal, untreated, and treated patients is shown in Figure 3. Although significant decreases were seen after treatment, absolute values remain high in comparison with those of the control group $(\mathrm{p}<0.001)$.

\section{Discussion}

The assessment of colonic mucosa by computerised image analysis has led to a reliable distinction between normal colorectal mucosa and adenocarcinoma, ${ }^{15}$ and has also aided the separation of normal colonic mucosa from adenoma and from adenocarcinoma. ${ }^{10}$ Morphometric analysis was also found to be of value in distinguishing regenerative hyperplasia from dysplasia $^{8}$ and separating high grade dysplasia from adenocarcinoma in patients with ulcerative colitis. ' A previous quantitative study ${ }^{5}$ in patients with ulcerative colitis and Crohn's disease has shown that the most discriminating factor is the surface to crypt cell height ratio. In another study ${ }^{9}$ in patients with ulcerative colitis, Crohn's disease, and proctitis, Jenkins et al found that the most powerful discriminant was increased lamina propria cellularity followed by the ratio of surface length to mucosal length and of surface to crypt cell height. In our study in untreated patients the area and height of surface epithelium and surface to crypt cell height ratio were reduced by about $50 \%$.

Unlike the previous authors we also found significant changes in the crypts, including a significant decrease in the total area of the crypts, appreciable reduction in goblet cells, widening and relative shortening (D/H ratio) of the crypts, and a significant increase in regenerative activity (mitotic index). The most important finding, however, that differentiates control subjects from untreated patients was the ratio of the areas of surface epithelium to lamina propria. In untreated patients there was a $75 \%$ decrease in 
this ratio compared with the control group. To the best of our knowledge this is the first study to describe quantitatively the vascularity of the lamina propria in control subjects, and untreated and treated patients with ulcerative colitis. The vascular area increased substantially in untreated patients, although this could be artefactual due to vasodilatation. Like Jenkins $e t a l,{ }^{9}$ we also found the number of polymorphs within the surface and crypt epithelium and crypt lumen to be significantly increased in untreated patients.

5 Amino salicylic acid is widely used in patients with ulcerative colitis. ${ }^{12}$ In our 12 patients who were taking this drug and completed the study, there were significant improvements in some of the post treatment parameters including cell height, area of surface epithelium, and the ratios surface to crypt cell height and surface to lamina propria areas. Treatment with 5ASA also led to some improvement in the crypts, which showed increases in area, goblet cell ratio, and number of nuclei with reduced polymorph infiltration. The two most important parameters which showed values approaching those of the control subjects were the area of surface epithelium and crypt to goblet cell ratio. Patients treated with rectal corticosteroids showed very similar morphometric improvements. As in patients treated with 5ASA, the goblet cell ratio of the crypt and the area of surface epithelium were the two most important parameters which improved after treatment to values not significantly different from those of the control subjects. Our finding that oral 5ASA led to morphometric improvements similar to those found with rectal steroid treatment are in agreement with those of Mulder et al,,$^{14}$ who recently described a clinical trial in 29 patients with active ulcerative colitis treated randomly with 5ASA and prednisolone enemas. Improvement was comparable in the two treated groups as assessed by clinical, endoscopic, and histological parameters.

An important finding in this study is that the cell height of the crypt epithelium did not alter significantly in control subjects and untreated and treated patients with ulcerative colitis. Similar findings were reported ${ }^{59}$ in control subjects and patients with ulcerative colitis, Crohn's colitis, and infective colitis. This may be due to the high regenerative activity that occurs in the lower zone of the crypt. ${ }^{16}$ Regenerative activity (mitotic index) was high in both untreated and treated patients. This led to an increase in the number of nuclei in the crypt and also to an increase in specialised goblet cells after treatment by 5 ASA and corticosteroids.

It is concluded from this study that both 5ASA and corticosteroids have similar effects on the rectal mucosa of patients with ulcerative colitis as assessed by morphometric analysis. The correlation between clinical, sigmoidoscopic, and histological findings assessed by quantitative morphometry may be valuable since previous studies $^{12+17-18}$ have used only simple histological criteria for this comparison and have not found significant correlations.

We are most grateful to Smith Kline and French (UK) for double blind packaging of the medications and financial assistance.

1 Rubio CA, Kock Y. A digital quantitative method of estimating inflammation in the rectal mucosa. I. The normal limits of asymptomatic patients. Scand $\mathcal{F}$ Gastroenterol 1981; 16: $731-5$.

2 Rubio CA, Johansson C, Kock Y. A quantitative method of estimating inflammation in the rectal mucosa. II. Normal limits in symptomatic patients. Scand $\mathcal{F}$ Gastroenterol 1982; 17: 1077-81.

3 Rubio CA, Johansson C, Kock Y. A quantitative method of estimating inflammation in the rectal mucosa. III. Chronic ulcerative colitis. Scand 7 Gastroenterol 1982; 17: 1083-7.

4 Rubio CA, Johansson C, Uribe A, Kock Y. A quantitative method of estimating inflammation in the rectal mucosa. IV. Ulcerative colitis in remission. Scand $\mathcal{F}$ Gastroenterol 1984; 19: 525-30

5 Thompson EM, Price AB, Altman DG, Sowter C, Slavin G. Quantitation in inflammatory bowel disease using computerised interactive image analysis. 7 Clin Pathol 1985; 38: 631-8.

6 Brown LJR, Smeeton NC, Dixon MF. Assessment of dysplasia in colorectal adenoma: an observer variation and morphometric study. $\mathcal{F}$ Clin Pathol 1985; 38: 174-9.

7 Allen DC, Hamilton PW, Watt PCH, Biggart JD. Morphometrical analysis in ulcerative colitis with dysplasia and metrical analysis in ulcerative colitis with

8 Allen DC, Hamilton PW, Watt PCH, Biggart JD. Architectural morphometry in ulcerative colitis with dysplasia.
allen DC, Hamilton PW, Histopathology 1988; 12: 611-21.

9 Jenkins D, Goodall A, Drew K, Scott BB. What is colitis? Statistical approach to distinguish clinically important inflammatory change in rectal biopsy specimens. $\mathcal{J}$ Clin Pathol 1988; 41: 72-9.

10 Graham AR, Paplanus SH, Bartels PH. Micromorphometry of colonic lesions. Lab Invest 1988; 59: 397-402.

11 Rachmilewitz D. Coated mesalazine (5-amino salicylic acid) versus sulphasalazine in the treatment of active ulcerative versus sulphasalazine in the treatment of active ulcer
colitis: a randomised trial. $\mathrm{Br}$ Med $\mathcal{F}$ 1989; 298: 82-6.

12 Riley SA, Mani V, Goodman MJ, Herd ME, Dutt S, Turnberg LA. Comparison of delayed release 5-amino salicylic acid (Mesalazine) and sulphasalazine maintenance treatment for patients with ulcerative colitis. Gastroenterology 1988; 94: 1383-9.

13 Danielsson A, Hellers G, Lyrenas E, et al. A controlled randomised trial of budesonide versus prednisolone retention enemas in active distal ulcerative colitis. Scand $\mathcal{F}$ Gastroenterol 1987; 22: 987-92.

14 Mulder CJJ, Tytgat GNJ, Wiltink EHH, Houthoff H-J. Comparison of 5-amino-salicylic acid (3g) and prednisolone phosphate socium enemas $(30 \mathrm{mg})$ in the treatment of distal uhosphate socium enemas ( $30 \mathrm{mg}$ ) in the treatment of distal ulcerative colitis. A prospective, randomised,
trial. Scand f Gastroenterol 1988; 23: 1005-8.

15 Hamilton PW, Allen DC, Watt PCH, Patterson CC, Biggart JD. Classification of normal colorectal mucosa and adenocarcinoma by morphometry. Histopathology 1987; 11: $901-$ 11.

16 Franklin WA, McDonald GB, Stein HO, et al. Immunohistologic demonstration of abnormal colonic crypt cell kinetics in ulcerative colitis. Hum Pathol 1985; 16: 1129-32.

17 Powell-Tuck J, Day DW, Buckell NA, Wadsworth J Lennard-Jones JE. Correlation between defined sigmoidoscopic appearance and other measures of disease activity in ulcerative colitis. Dig Dis Sci 1982; 27: 533-7.

18 Floren C-H, Benoni C, Willen R. Histologic and colonoscopic assessment of disease extension in ulcerative colitis. Scand $\mathcal{J}$ Gastroenterol 1987; 22: 459-62.

19 Binder V. A comparison between clinical state, macroscopic and microscopic appearances of rectal mucosa, and cytologic picture of mucosal exudate in ulcerative colitis. Scand $\mathcal{F}$ Gastroenterol 1970; 5: 627-32. 